\title{
MIGRATIONS AND THE DISSEMINATION OF MALARIA IN BRAZIL
}

\author{
AGOSTINHO CRUZ MAROUES
}

The great increase of migrations towards the Amazon region and the shifts of populations within the region have led to a considerable rise in the transmission of malaria. According to the 1980 Census, the Amazon region had the greatest populational growth rate in the country during the 1970.80 period. The Amazon grew at the rate of $5.04 \%$ a year, followed by the Central-Western regions with $4.04 \%$, both regions benefitting from the increase in the area used for farming. The North received over 900,000 migrants, which meant a significant increase in the overall population of the region, a fact that does not occur in any of the other regions. Rondonia was the Administrative Unit of the Federation that received the greatest number of the migrants to the Amazon region. The population of Rondônia increased considerably as a result of the agricultural settlement projects of the National Institute for Settlement and Land Reform (INCRA), whose main emphasis was on small and medium size farms. In less than 10 years, cities, towns and villages sprung up and more than 30,000 new farms were started, concentrated mostly along BR-364, the Porto Velho-Cuiabá highway (Marques, 1983).

The 1980 Census showed that the largest migration flows towards Rondonia originated in the rural areas of the Central-Southern, Southern and South-Eastern regions. The migration flows towards the State of Para started in the Northeastern region, particularly in the neighboring State of Maranhão. These were mostly people attracted toward the gold prospecting and mining operations, agricultural projects, settlement areas along the Transamazon highway, and other similar activities. The migration flows toward the Northern part of the State of Mato Grosso, which had the smallest populational growth during the period of $3.45 \%$, originated in the more developed states of the South-Eastern and Southern regions.

During the $80 \mathrm{~s}$, migrations reached an even higher level. The population of Rondonia doubled between 1981 and 1985 , from 570,000 to $1,040,000$ inhabitants. The 5,000 participants in settlement projects in the State of Acre in 1981 had increased to 33,600 by the end of 1985, an increase of over $600 \%$. The Roraima population was 80,000 in 1980 and had grown to 160,000 by the end of last year, having doubled in the last five years, mainly as a result of the INCRA settlement projects that created the municipalities of São Luiz and São João da Balisa.'

In the Southern part of the State of Pará, the discovery of the Serra Pelada gold mine in Marabá and of new gold-rich areas not only in Marabá but also in the neighboring municipalities, particularly São Felix do Xingu, gave rise to new flows of migrants from the rural areas of the nearby States of Maranhāo, Piauí, Goiás and Ceará, thus increasing the population of the mining areas two-fold during the ' 80 s.

Consequently, the transmission of malaria has gradually risen. In 1985, there was a slight halt in the progressive spread of the disease that probably reflects the control measures undertaken, which focused on the most critical areas. Epidemiological data on malaria for the Legal Amazon Region, covering the last five years (1981-85) show that the disease doubled during that period, as shown in Table $I$.

\section{TABLE I}

Number of recorded malaria cases in the Legal Amazon Region 1981-1985

\begin{tabular}{lccccc}
\hline Tests and Indexes & 1981 & 1982 & 1983 & 1984 & 1985 \\
\hline No. of lab tests performed & $1,318,959$ & $1,352,264$ & $1,565,659$ & $1,894,458$ & $2,034,120$ \\
No. of positives & 189,319 & 214,650 & 289,990 & 364,984 & 384,603 \\
Positives index (ILP) & 14,4 & 15,9 & 18,3 & 19,3 & 18,9 \\
Annual parasite incidence (IPA) & 15,0 & 16,0 & 20,7 & 25,3 & 23,7 \\
(IPA) = No. of cases/1,000 inhab.) & & & & \\
\hline
\end{tabular}

SUCAM - Superintendência de Campanhas de Saúde Pública. Ministéno da Saúde - Esplanada dos Ministérios, 70058, Brasília, DF, Brasil. 
In 1985, the epidemiological data shown 168,000 positive tests in Rondônia, most of them from the agricultural settlement projects with a strong influence from the gold mining operations in the municipalities of Porto Velho and Guajará Mirim; in the municipalities of Colider, located in the Northern part of Mato Grosso, close to 4,000 cases were recorded among prospecting/mining personnel; while in the Southern part of the State of Pará, 80,000 laboratory tests showed the presence of the malaria parasites in miners and agricultural workers. Table II lists the municipalities with the highest number of cases within the Legal Amazon Region and the main features of the process of transmission (settlements, mining, agricultural projects). These municipalities are shown in Map 1.

TABLE II

Municipalities with the largest number of malaria cases within the Legal Amazon Region for 1985

\begin{tabular}{|c|c|c|c|c|c|}
\hline \multirow[b]{2}{*}{ Unit } & \multirow[b]{2}{*}{ Municipality } & \multicolumn{2}{|c|}{ Blood Samples } & \multirow[b]{2}{*}{ ILP } & \multirow[b]{2}{*}{ Main Activity } \\
\hline & & Tests & + & & \\
\hline Rondônia: & $\begin{array}{l}1 \text { Ariquemes } \\
2 \text { Porto Velho } \\
3 \text { Pres. Medici } \\
4 \text { Jaru } \\
5 \text { Jy-Paraná } \\
6 \text { Rolim de Moura } \\
7 \text { Guajará Mirim } \\
8 \text { Ouro Pre to }\end{array}$ & $\begin{array}{r}115,532 \\
90,658 \\
58,928 \\
62,288 \\
37,261 \\
23,278 \\
21,672 \\
30,018\end{array}$ & $\begin{array}{r}38,287 \\
31,515 \\
22,794 \\
18,725 \\
13,524 \\
8,130 \\
7,789 \\
7,686\end{array}$ & $\begin{array}{l}33,1 \\
34,8 \\
38,7 \\
30,1 \\
36,3 \\
34,9 \\
35,9 \\
25,6\end{array}$ & $\begin{array}{l}\text { Settlements } \\
\text { Set \& mining } \\
\text { Settlements } \\
\quad " \\
\quad " \\
\quad " \\
\text { Set \& mining } \\
\text { Settlements }\end{array}$ \\
\hline Pará: & $\begin{array}{l}9 \text { Sāo Félix đo Xingu } \\
10 \text { Itaituba } \\
11 \text { Marabá } \\
12 \text { Redençāo (*) } \\
13 \text { Santana Araguaia } \\
14 \text { Santarém (**) } \\
15 \text { Paragominas } \\
16 \text { Portel }\end{array}$ & $\begin{array}{r}61,183 \\
39,539 \\
38,848 \\
12,569 \\
17,917 \\
15,194 \\
9,137 \\
12,646\end{array}$ & $\begin{array}{r}30,857 \\
14,324 \\
12,180 \\
6,025 \\
5,385 \\
3,751 \\
3,491 \\
3,140\end{array}$ & $\begin{array}{l}50,4 \\
36,2 \\
31,4 \\
47,9 \\
30,1 \\
24,7 \\
38,2 \\
24,8\end{array}$ & $\begin{array}{c}\text { Mining } \\
\qquad " \\
\text { Agriculture } \\
\quad- \\
\text { Agriculture } \\
\text { Settlements }\end{array}$ \\
\hline Mato Grosso: & 17 Colider & 21,032 & 4,167 & 19,8 & Mining \\
\hline Roraima: & 18 Boa Vista & 23,365 & 11,983 & 32,7 & Settlements \\
\hline Amapá: & 19 Macapá & 18,831 & 5,493 & 29,9 & Set. \& mining \\
\hline Maranhão: & 20 Imperatriz & 16,241 & 4,194 & 25,8 & Settlements \\
\hline
\end{tabular}

(*) Influenced by S. Félix do Xingu with respect to the origin of the cases.

(*) Influenced by Itaituba with respect to the origin of the cases. 


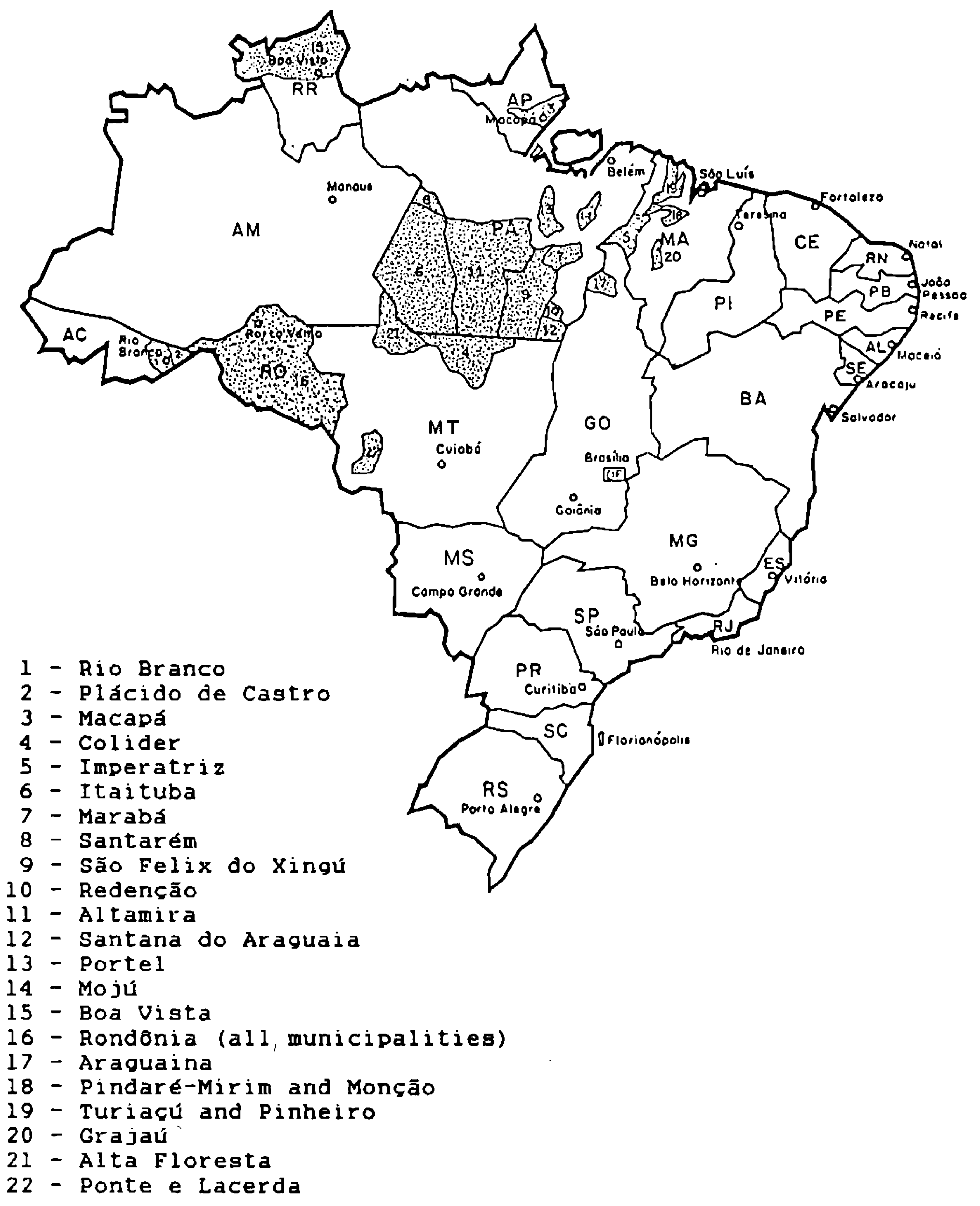

Map 1 - Municipalities with high malaria transmission rates in 1985

\section{MATERIALS AND METHODS}

The present paper is based on the results of the epidemiological investigations of malaria cases. Some clarifications are necessary to understand the importance of this work.

The investigation of malaria cases is linked to the epidemiological activities of the malaria program and helps to identify the origin of the cases and the circumstances under which the transmission occurred. It is carried out in the field by SUCAM inspectors as well as in the laboratories, so that, throughout the country, this task is repeated in thousands of villages or towns, within hundreds of municipalities. 
The malaria programs have priorities in the investigation of malaria cases. These priorities are a function of the rating of the area wherein the case occurred, the current phase of the program in that area and the specific nature of the infection. The priority to be given to an investigation follows the sequence below:

(i) cases discovered in a non-malaric area; (ii) cases discovered in a malaric area that is in the consolidation or maintenance phase; (iii) cases discovered in an area in the attack phase, according to the specificity of the infection (infections by $P$. falciparum shall have priority over infections by $P$. vivax).

SUCAM tries to investigate all cases which are recorded within the short term erradication areas, that is, endemic areas outside the Legal Amazon Region in which transmission is limited to residual areas and new active foci. Within the Legal Amazon Region, in Priority I areas, where there is a great deal of transmission, investigations are carried out only at the local "Directorate" and "District" headquarters. For Priority II areas, where fewer cases occur, an effort is made to investigate the greatest possible number of cases, although it is only a preliminary investigation, limited to the category of the case and the identification of the point of origin. In 1985, SUCAM carried out 54,449 investigations throughout the country, 40,530 of which in the Legal Amazon Region and 13,919 outside the Amazon, the latter being $93,7 \%$ of all cases in the area. These data are shown in Table III.

TABLE III

Epidemiological investigations of malaria cases carried out in 1985

\begin{tabular}{|c|c|c|c|c|c|c|c|c|c|}
\hline \multirow{2}{*}{\multicolumn{2}{|c|}{$\begin{array}{c}\text { Unit } \\
\text { of the } \\
\text { Federation }\end{array}$}} & \multirow[b]{2}{*}{ Recorded } & \multicolumn{3}{|c|}{ Number of cases } & \multicolumn{2}{|c|}{ Autochthonous } & \multicolumn{2}{|c|}{ Others } \\
\hline & & & Investigate & & $\%$ & No. & $\%$ & No. & $\%$ \\
\hline \multicolumn{10}{|c|}{ Legal Amazon } \\
\hline 1 & Rondônia & 168,690 & 1,919 & & 1.1 & 1,845 & 96,1 & 74 & 3.9 \\
\hline 2 & Acre & 10,120 & 5,610 & & 55.4 & 3,919 & 69.9 & 1,691 & 30,1 \\
\hline 3 & Roraima & 15,836 & 328 & & 2.1 & 317 & 96.6 & 11 & 3.4 \\
\hline 4 & Amazonas & 11,198 & 5,575 & & 49.8 & 3,537 & 63.4 & 2,038 & 36.6 \\
\hline 5 & Pará & 113,649 & 1,160 & & 1.0 & 884 & 76.2 & 27 & 23.8 \\
\hline 6 & Amapá & 7,461 & 4,116 & & 55.2 & 4,033 & 98.0 & 83 & 2.0 \\
\hline 7 & Maranhāo & 37,889 & 14,981 & & 39.5 & 6,580 & 43.9 & 8,401 & 56.1 \\
\hline 8 & Goiás (Northem) & 6,928 & 4,721 & & 68.1 & 1,867 & 39.5 & 2,850 & 60.5 \\
\hline 9 & Mato Grosso & 128,832 & 2,120 & & 16.5 & 1,345 & 63.4 & 775 & 36.6 \\
\hline & Sub-total & 384,603 & 40,530 & & 10.5 & - & & - & \\
\hline \multicolumn{10}{|c|}{$\begin{array}{l}\text { Area-outside } \\
\text { the Amazon }\end{array}$} \\
\hline 10 & Piauí & 3,080 & 2,790 & & 90.6 & 328 & 11.8 & 2,462 & 88.2 \\
\hline 11 & Ceará & 859 & 837 & & 97.4 & 103 & 12.3 & 734 & 87.7 \\
\hline 12 & Rio Grande do Noite & 132 & 125 & & 94.7 & 1 & 0.8 & 124 & 99.2 \\
\hline 13 & Paraiba & 131 & 131 & & 100.0 & 0 & 0.0 & 131 & 100.0 \\
\hline 14 & Pernambuco & 152 & 140 & & 92.1 & 0 & 0.0 & 140 & 100.0 \\
\hline 15 & Alagoas & 28 & 28 & & 100.0 & 0 & 0.0 & 28 & 100.0 \\
\hline 16 & Sergipe & 10 & 10 & & 100.0 & 0 & 0.0 & 10 & 100.0 \\
\hline 17 & Bahia & 624 & 601 & & 96.3 & 294 & 48.9 & 307 & 51.1 \\
\hline 18 & Minas Gerais & 1,061 & 1,001 & & 94.3 & 10 & 1.0 & 991 & 99.0 \\
\hline 19 & Espírito Santo & 299 & 283 & & 100.0 & 4 & 1.4 & 279 & 98.6 \\
\hline 20 & Rio de Janeiro & 216 & 218 & (a) & 100.0 & 18 & 8.3 & 200 & 91.7 \\
\hline 21 & Paraná & 1,738 & 1,760 & (a) & 100.0 & 12 & 0.7 & 1,748 & 99.3 \\
\hline 22 & Santa Catarina & 81 & 77 & & 95.1 & 0 & 0.0 & 77 & 100.0 \\
\hline 23 & Goiás (Southem) & 2,106 & 1,947 & & 92.5 & 132 & 6.8 & 1,815 & 93.2 \\
\hline 24 & Mato Grosso do Sul & 1,385 & 1,195 & & 86.3 & 61 & 5.1 & 1,134 & 94.9 \\
\hline 25 & Distrito Federal & 578 & 578 & & 100.0 & 1 & 0.2 & 577 & 99.8 \\
\hline 26 & São Paulo & 2,202 & 2,198 & & 99.8 & 44 & 2.0 & 2,154 & 98.0 \\
\hline \multirow[t]{3}{*}{27} & Rio Grande do Sul & 177 & - & & 0.0 & . & $\cdots$ & & \\
\hline & Sub-total & 14,859 & 13,919 & & 93,7 & 1,008 & 7.2 & 12,911 & 92.8 \\
\hline & Grand Total & 399,462 & 54,449 & & 13.6 & - & & - & \\
\hline
\end{tabular}

(a) Including previous year cases. 
The procedure followed in an epidemiological investigation is summarized below:

- after a case has been confirmed through laboratory tests, the investigation is started using Form EP-310 ("Investigation of Cases"), that includes the case history and identification, spraying record of the house and final analysis of the origin of the case. The microscopist at the laboratory writes the name, age and residence of the patient and the number, result and data of the test in the EP-310 form;

- the EP-310 form is then forwarded to the area Inspector who enters other basic information ("other information about the patient"), adding details about any travel by the patient or other facts which may help to elucidate the origin of the case (the Inspector takes a series of steps: collects blood samples from relatives and neighbors who are feverish, initiates radical treatment of the patient being investigated, etc.);

- once the malariologist has all this information, he will be able to establish which category the case belongs to, and will proceed to fill in the second part of the EP-310 form, namely the item "assessment by the malariologist", and will provide proper guidance for focus delimitation;

-- the results of the EP-310 form are consolidated into another form, EP.322 ("Summary of the epidemiological investigations and measures taken"), which is completed by the Regional Directorate on a monthly basis and sent to the Malaria Division of SUCAM, where it is analyzed. This bulletin was one of the most important sources of the data for this paper. The EP-322 form gives the identification number of the investigation; the place where the patient lives (municipality and township); the place where the case was discovered; the species and density of the parasite; the dates of the collection, examination and investigation of the case; the data on which the field measures were started (treatment, active special search, spraying); the identification of the probable place of transmission; and, finally, the classification of the case by geographical area (Marques \& Pinheiro, 1982).

Any other information needed for the report is obtained from the documents on file at the Malaria Division and the Regional Directorate, such as assessment reports, analyses of the epidemiological situation and statistical data.

\section{RESULTS}

The results of the epidemiological investigations show a strong influence of the high transmission areas, not only on the local and regional epidemiology but also on the malaria situation in far away states, as a consequence of the moving about of the cases. Table IV gives two examples: the first in a gold mining zone and the second in a settlement area; in both cases, the scattering of the cases from a generating source is obvious. The spatial dissemination of malaria was due to the return of the migrants to their places of origin.

TABLE IV

Influence of a mining zone ("Cumaru" - Pará Project) and a settlement area (Ariquemes - Rondônia Municipality) on the epidemiology of malaria on other Brazilian units of the Federation in 1985

\begin{tabular}{|c|c|c|c|c|c|c|}
\hline $\begin{array}{l}\text { Mining } \\
\text { Zone }\end{array}$ & $\begin{array}{l}\text { Receiving } \\
\text { State }\end{array}$ & $\begin{array}{r}\text { No. of } \\
\text { cases }\end{array}$ & $\begin{array}{l}\text { Settlement } \\
\text { Zone }\end{array}$ & \multicolumn{2}{|c|}{$\begin{array}{l}\text { Receiving } \\
\text { State }\end{array}$} & $\begin{array}{l}\text { No. of } \\
\text { cases }\end{array}$ \\
\hline $\begin{array}{l}\text { "Cumaru" Project in the } \\
\text { Sāo Félix do Xingu } \\
\text { Municipality in the } \\
\text { State of Pará }\end{array}$ & $\begin{array}{l}1 \text { Maranhão } \\
2 \text { Piauí } \\
3 \text { Goiás } \\
4 \text { Ceará } \\
5 \text { Rio G. do Norte } \\
6 \text { Paraiba } \\
7 \text { Pernambuco } \\
8 \text { Bahia } \\
9 \text { Minas Gerais } \\
10 \text { São Paulo } \\
11 \text { Distrito Federal } \\
\text { Total }\end{array}$ & $\begin{array}{r}5,100 \\
1,282 \\
1,760 \\
210 \\
16 \\
11 \\
42 \\
20 \\
66 \\
57 \\
119 \\
8,683\end{array}$ & $\begin{array}{l}\text { Ariquemes } \\
\text { Municipality } \\
\text { in the State of } \\
\text { Rondônia }\end{array}$ & $\begin{array}{r}1 \\
2 \\
3 \\
4 \\
5 \\
6 \\
7 \\
8 \\
9 \\
10\end{array}$ & $\begin{array}{l}\text { Bahia } \\
\text { Espírito Santo } \\
\text { Minas Gerais } \\
\text { São Paulo } \\
\text { Distrito Federal } \\
\text { Paraná } \\
\text { Santa Catarina } \\
\text { Mato Grosso } \\
\text { Mato G. do Sul } \\
\text { Goiás } \\
\text { Total }\end{array}$ & $\begin{array}{r}116 \\
48 \\
110 \\
245 \\
21 \\
319 \\
12 \\
103 \\
97 \\
63 \\
1,134\end{array}$ \\
\hline
\end{tabular}

Source: Epidemiological Investigation Bulletins of the Malaria Division of SUCAM.

SUCAM's statistical data show the growth of malaria outside the Amazon region: 7,289 cases in 1982; 10,697 in 1983; and 14,859 in 1985. It must be stressed, however, that this increase is not due to a rise in transmission but it is rather a consequence of the outward flow of cases from 
the Legal Amazon Region. Of the 14,859 cases recorded in 1985, 13,919 were investigated, or $93.7 \%$ of all cases, out of which 1,008 cases were classified as "autochthonous" (resulting from local transmission). In other words, only $7 \%$ of the total number of recorded cases within the short term erradication area were caused by local transmission. Comparing the 1,008 cases mentioned with the total number of positives for the whole country in 1985, it can be seen that they represent only $0.25 \%$. It can be concluded, therefore, that the Legal Amazon Region accounts for over $99 \%$ of the malaria cases in Brazil.

In terms of the epidemiological surveillance, the return of migrants from the Amazon to their places of origin may mean the reintroduction of malaria in those areas. The process is initiated with the emergence of new active foci which demand forceful and timely treatment so that these new roci be "silenced". In 1985, 26 new active foci were recorded in the States of Piauí, Ceará, Bahia, Minas Gerais, Rio de Janeiro, and Mato Grosso do Sul, with the greatest epidemiological significance being given to the Northeastern States' foci, which accounted for $80 \%$ of all cases detected. Of these foci, six were still active by the end of 1985, while the remainder had already been eliminated.

Maps 2, 3 and 4 show in a schematic manner, the travel of the malaria cases from the main generating sources (high transmission zones), located in the States of Pará, Rondonia and

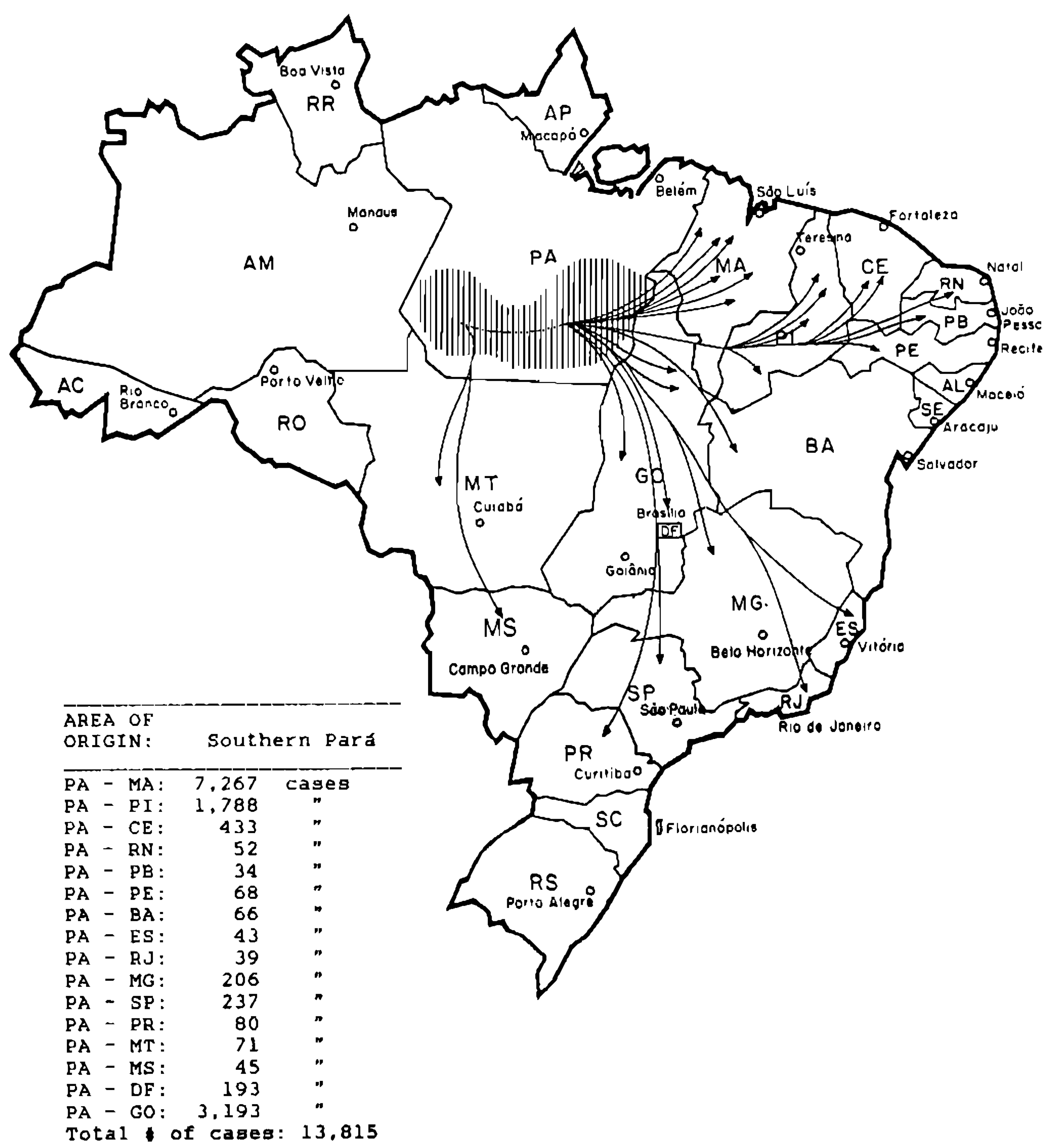

Map 2 - Destination of malaria cases who left Pará for other Units of the Federation in 1985 
Mato Grosso, to the States which are in the short term erradication stage. The preliminary results of the epidemiological investigations show, by Administrative Unit of the Federation, the pressure on the malaria situation brought about by the arrival of malaria patients. The information may be summarized as follows:

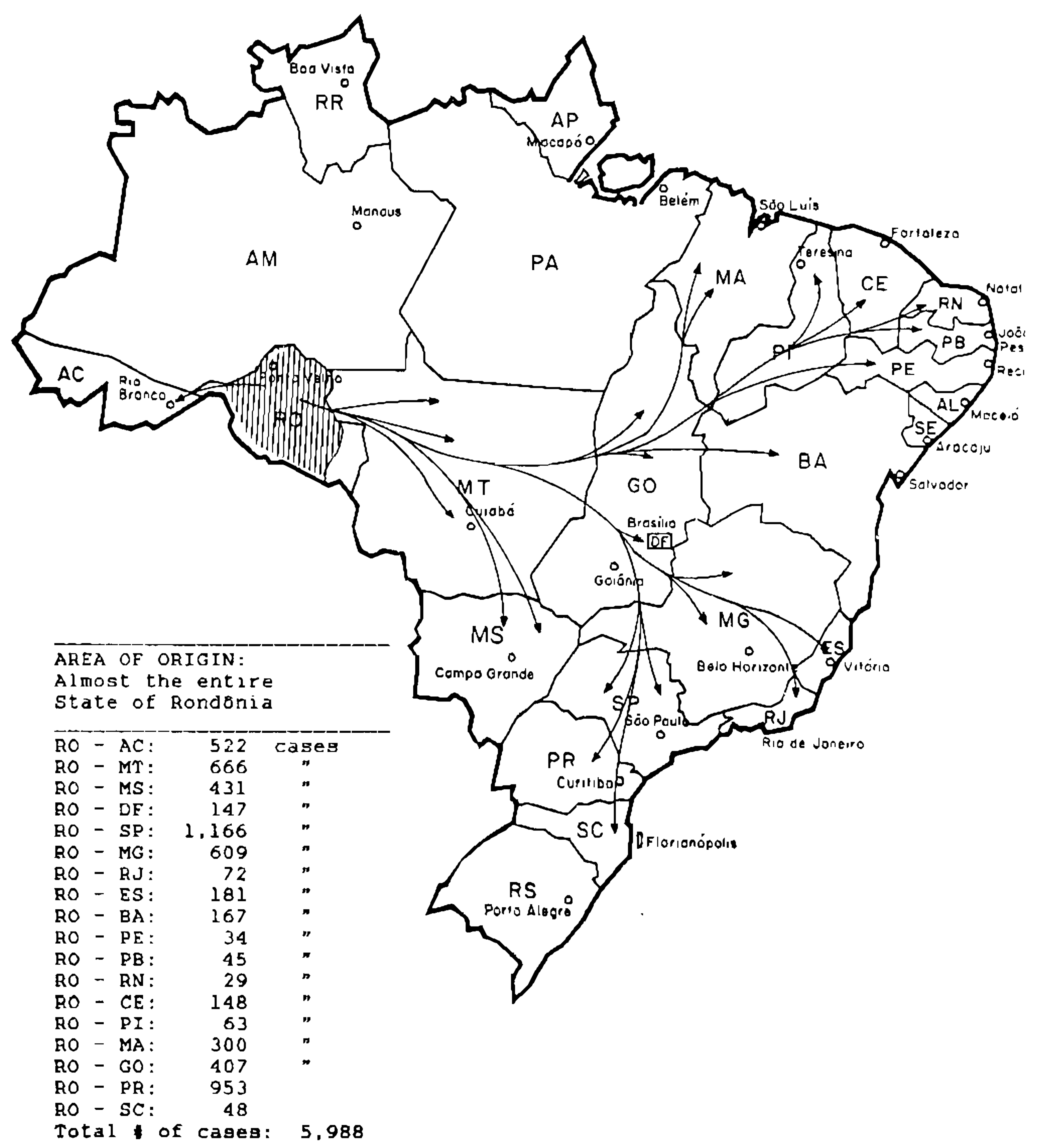

Map 3 - Destination of malaria cases who left Rondônia for other Units of the Federation in 1985 


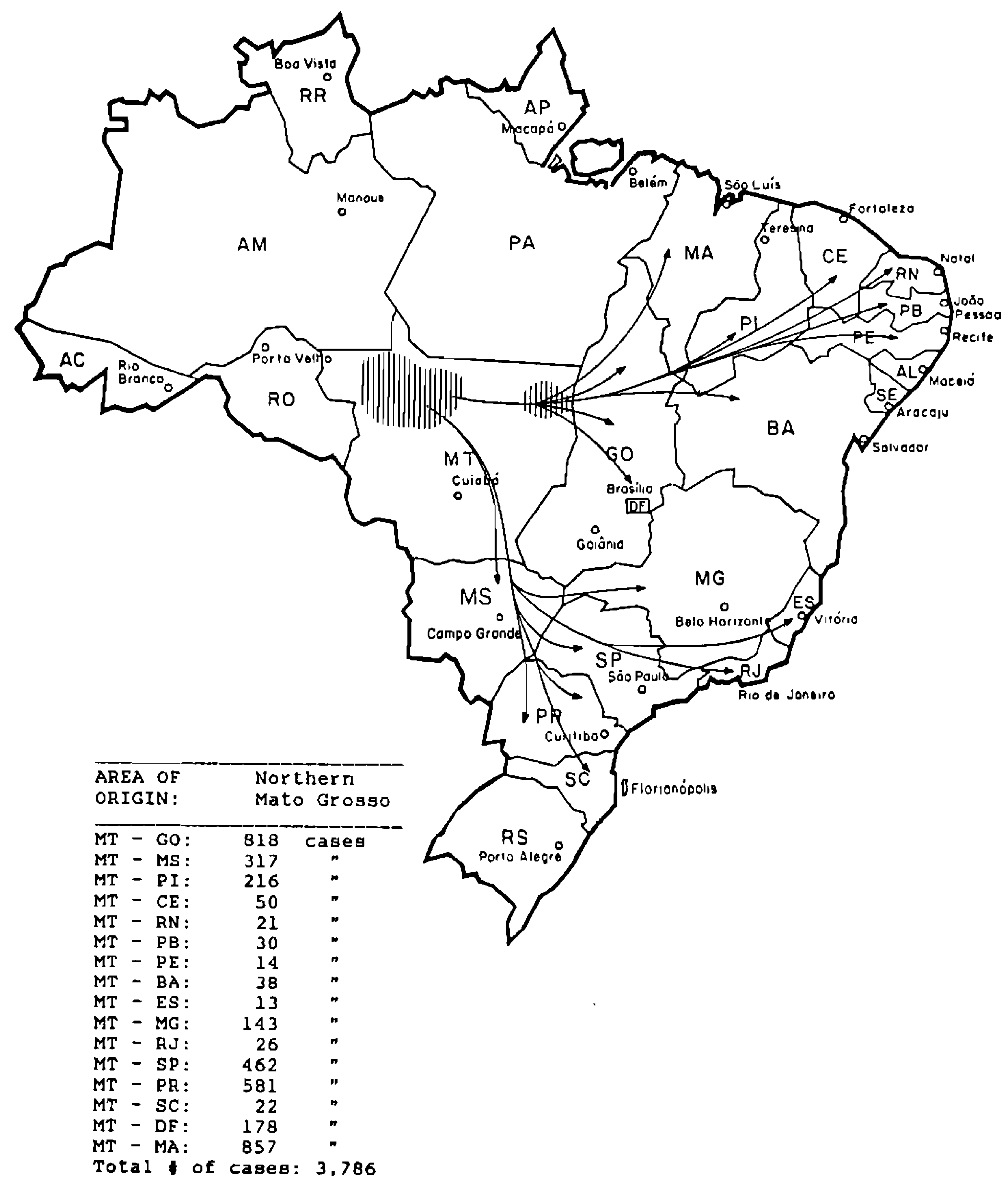

Map 4 - Destination of malaria cases who left Mato Grosso for other Units of the Federation in 1985.

Piaui. Of the 2,775 investigations carried out, 2,288 cases were identified as imported from the Amazon region (82.4\%), most of whom came from Pará $(1,788$ cases or $78.1 \%$ of imported cases). Coming from São Félix do Xingu 1,145 malaria carriers were detected in miners scattered throughout 78 municipalities. Other places of origin were: Mato Grosso (216 cases), Maranhão (162); and several other units (Rondônia 62, Amapá 27, Goiás 16, Amazonas 9, Roraima 6, and Bahia 1). Besides those coming from São Félix do Xingu, cases in miners were also confirmed from Itaituba (198) and Marabá (147), both municipalities in the State of Pará. 
Ceará. Out of 834 investigations, 728 cases imported from the Amazon region were identified, most of whom came from the State of Pará (433), particularly from the mining operations in São Félix do Xingu (210). Other origins were: Rondônia (148), Mato Grosso (50) - the mining operations of Colider were responsible for 43 cases - and several units (Amapá 30, Maranhão 25, Roraima 11, Goiás 11, Amazonas 10, and Acre 7). The total number of cases registered in miners reached a total of 509 cases, or $70 \%$ of the total number of imported cases.

Rio Grande do Norte. All the cases were imported from the Amazon region (125), most of them came from Pará (52). Other sources of cases: Rondônia (29), Mato Grosso (2) and Amapá (14). Most cases came from mining operations (Itaituba 22, São Félix do Xingu 16, Calcoene 14, and Colider 13).

Paraíba. All cases were imported from the Amazon Region (131). Their origin was as follows: Rondònia (45), Pará (34), Mato Grosso (30), and other units (22). Approximately 47 cases came from mining operations.

Pernambuco. All the cases were imported from the Amazon region (140) - 68 from Pará; 34 from Rondônia; 14 from Mato Grosso, 12 from Maranhão; and 12 from other units. Approximately 65 cases were miners.

Alagoas. Although the number of cases was small (28), all of them were imported from the Amazon region, although the number was small (28). Distribution according to source: Pará (13), Rondônia (9), Mato Grosso (5), and Acre (1).

Sergipe. A small number of cases was recorded and investigated (10), all of whom came from the Amazon region (Amapá 4, Rondônia 3, Pará 2, and Amazonas 1).

Bahia. Out of the 598 investigations carried out, 284 were classified as imported cases. The source of the cases was as follows: Rondônia 167, Pará 66, Mato Grosso 38, and other units 10. Special emphasis must be given to the Municipality of Ariquemes (116), which is a settlement area. The mining operations originated more than 60 patients (São'Felix do Xingu 20, Colider 17, Alta Floresta 16, Itaituba 8, Marabá 7).

Espírito Santo. Out of 288 investigations, 249 cases imported from the Amazon region were identified. Their distribution in terms of origin of the transmission is as follows: Rondônia 181, Pará 43 and other units 19. The settlement areas contributed 137 cases and the mining operations 48.

Rio de Janeiro. There were 151 cases imported from the Amazon region out of 234 investigations, with great diversification with regards to origin: Rondônia 72 , Pará 39 , Mato Grosso 26 , and others 14 , including five cases who came from Africa.

Minas Gerais. Out of the 999 investigations which were concluded, 984 cases proved to be imported. Their origin was as follows: Rondônia (609), Pará (206), Mato Grosso (143), and others (41). Most of the cases came from settlement areas (Porto Velho 173, Ariquemes 110, Jiparaná 54, $\mathrm{J}$ aru $51, \ldots)$, although there was a noteworthy contribution of cases from the mining operations (São Félix do Xingu 66, Itaituba 46, Colider 54, Alta Floresta 43, ...).

São Paulo. SUCEN completed 2,198 investigations, mostly of cases imported from the Amazon region $(2,064)$. Their origin was as follows: Rondônia $(1,166)$, Mato Grosso $(462)$, Pará (237), and others (199). Among the latter, emphasis should be given to Acre (34), Amazonas (25) and Goiás (29). There was a relevant contribution from the settlement areas - Porto Velho (327), Ariquemes (245), Costa Marques (75), Jiparaná (51), and Guajará Mirim (56). The mining operations were responsible, however, for the largest share (close to 640 cases), with special emphasis given to Periquitos (168), Peixoto de Azevedo (134), Itaituba (61) and São Félix do Xingu (57). Forty cases came from the agricultural zones in the South of the State of Para (Santana do Araguaia and others).

Paraná. In the State of Paraná, there were 1,737 imported recorded cases of malaria, most of them from the Amazon region (excluding 57 cases from Paraguay and 11 from the State of Mato Grosso do Sul). Most of these imported cases came from Rondônia (953) because of the many cases originating in the settlement projects - special stress must be laid on Ariquemes (319), Porto Velho (114), Costa Marques (86), Presidente Médici (79), Rolim de Moura (73), and Jaru (53). Mato Grosso had an important participation as origin of many malaria cases (581), although in this State most cases came from the mining operations - Colider (357) and Alta Floresta (126). Other cases came from Pará (80), Amazonas (14), etc. 
Santa Catarina. Out of 77 cases investigated, 75 were imported from the Amazon region, most of which from Rondônia (48) and Mato Grosso (22).

Mato Grosso do Sul. Out of the 1,196 investigations carried out, 1,095 cases were identified as imported. These cases originated in the States of Rondònia (431), Mato Grosso (317), Pará (45), and others (31) as well as from Paraguay (237). The latter cases were Brazilians coming back from that country. The municipalities with the greatest share of cases were the following: Porto Velho (100), Ariquemes (97), and Presidente Médici (51) in the State of Rondônia; and Colider (169), Alta Floresta (40), and Pontes e Lacerda (36) in the State of Mato Grosso. In Paraguay, the Departments of Capitán Bado (84) and Caneudevy (66) had the largest participation in the transmission process.

Distrito Federal. There were 567 cases imported from the Amazon region, out of 577 investigations. Their origin were Pará (193), Mato Grosso (178), Rondônia (147), and others (55). There were four cases originating in Africa. The largest group was the miners (338 cases), with special emphasis for the mining operations in Peixoto de Azevedo (Colider) with 109 cases and the Cumaru Project (Sāo Félix do Xingu) with 97 cases.

Goiás. Goiás is included in this region because it is partially in the short term erradication area. Out of 6,668 cases investigated, 4,851 were identified as cases imported from the Amazon region. These cases originated in Pará $(3,193)$, Mato Grosso (407) and several others (251). The municipalities responsible for the largest number of cases were: São Félix do Xingu $(1,760)$, Santana do Araguaia (541), Conceição do Araguaia (275), Marabá (214), and Itaituba (115) in the State of Pará; Colider (247), Barra do Garças (168), Luciara (138), and Alta Floresta (72) in the State of Mato Grosso; and Porto Velho (193) in the State of Rondônia. The cases originating in mining operations (close to 2,400 ) were more numerous than those coming from settlement areas or agricultural projects (approximately 1,400 ).

The investigations carried out in the Amazon region showed the influence of migrations from rural to urban areas in the transmission of malaria in the periphery of the cities, including the State or Territorial Capital cities (Porto Velho, Macapá, Boa Vista, Rio Branco, ...) where the number of autochthonous cases in the zones of expansion of the cities is about $10 \%$. In some cities, transmission reaches higher values, such as in the case in the cities of Ariquemes in the State of Rondônia and Plácido de Castro in the State of Acre.

\section{DISCUSSION}

Considering the information presented in the previous pages, there is no doubt that the travels of people are contributing to the dissemination of malaria in Brazil. It must also be considered that malaria itself has been one of the factors that have led some settlers to give up the settlement projects in those areas which are not very appropriate for human settlements or that can even be considered as totally uninhabitable because of the very high malaria transmission rates. Very often the transmission rates have led to a redistribution of the settlement populations. There are many examples of people who could not remain in the INCRA settlement projects in Rondônia or along the highways that are built in the Amazon region.

On one hand, there is the problem of propagation of this endemic disease from one area to another, through the carrying of the pathogenic agents in the migration flows. On the other hand, there is the entering of man into an ecological environment that harbors natural foci of diseases which the migrating population did not know in the places of origin (CDMS, 1982).

The present interplay between travel and malaria is a matter of great concern. Many more people are migrating than ever before. The opening of great highways that cut through the Amazon region - such as Belém-Brasília, Porto Velho-Cuiabá, Manaus-Porto Velho, CuiabáSantarém, Manaus-Caracaraí, and the Trans-Amazon highways, as well as parts of the Northern Perimeter highways that are very much used by settlers and miners - have been instrumental in providing access to regions that were totally uninhabited less than twenty years ago. There has been an expansion of the malaria area with the settlement of vast regions which are either being settled or exploited. Also, these regions have very scarce or non-existant medical services and the health care of the migrants is at best precarious. It is therefore impossible to control the diseases they carry.

The manner in which the Amazon area is being settled has led to a very great increase of malaria in this region on account of such circumstances as: huge waves of migrants; ecological 
imbalances due to the clearing of the native vegetation or to other activities such as prospecting and mining; very poor living conditions and sanitation; lack of information on the part of the migrants about the forms of transmission and prevention measures; precarious health care services; poor transportation, communications and basic services, like education, etc. (Paula, 1986).

Most malaria cases are concentrated in two States: Rondonia and Pará. Together, they accounted for $70 \%$ of all cases in Brazil in 1985 . This concentration of malaria is certainly related to the fact that these two States are at the forefront of the expansion of the agricultural fronteer in Brazil and of the rapid settlement of migrant populations. These populations become scattered throughout the area and engage in activities in which the contact with both forest and water is inevitable. The settlement of the land and the economic exploitation of the region bring about a deep interaction of the migrants with the environment. Frequently this interaction results in various degrees of ecological imbalance, which contribute to new epidemic outbreaks (Paula, 1986).

Two types of activities have led to the worsening of the transmission of malaria in the Amazon region: prospecting/mining and settlements. In both cases, man is exposed to the aggression of the vectors that already exist in the environment. Also, the fact that both miners and settlers are considerably scattered (see Maps 5 and 6) has prevented the decrease of the contact between man and vector.

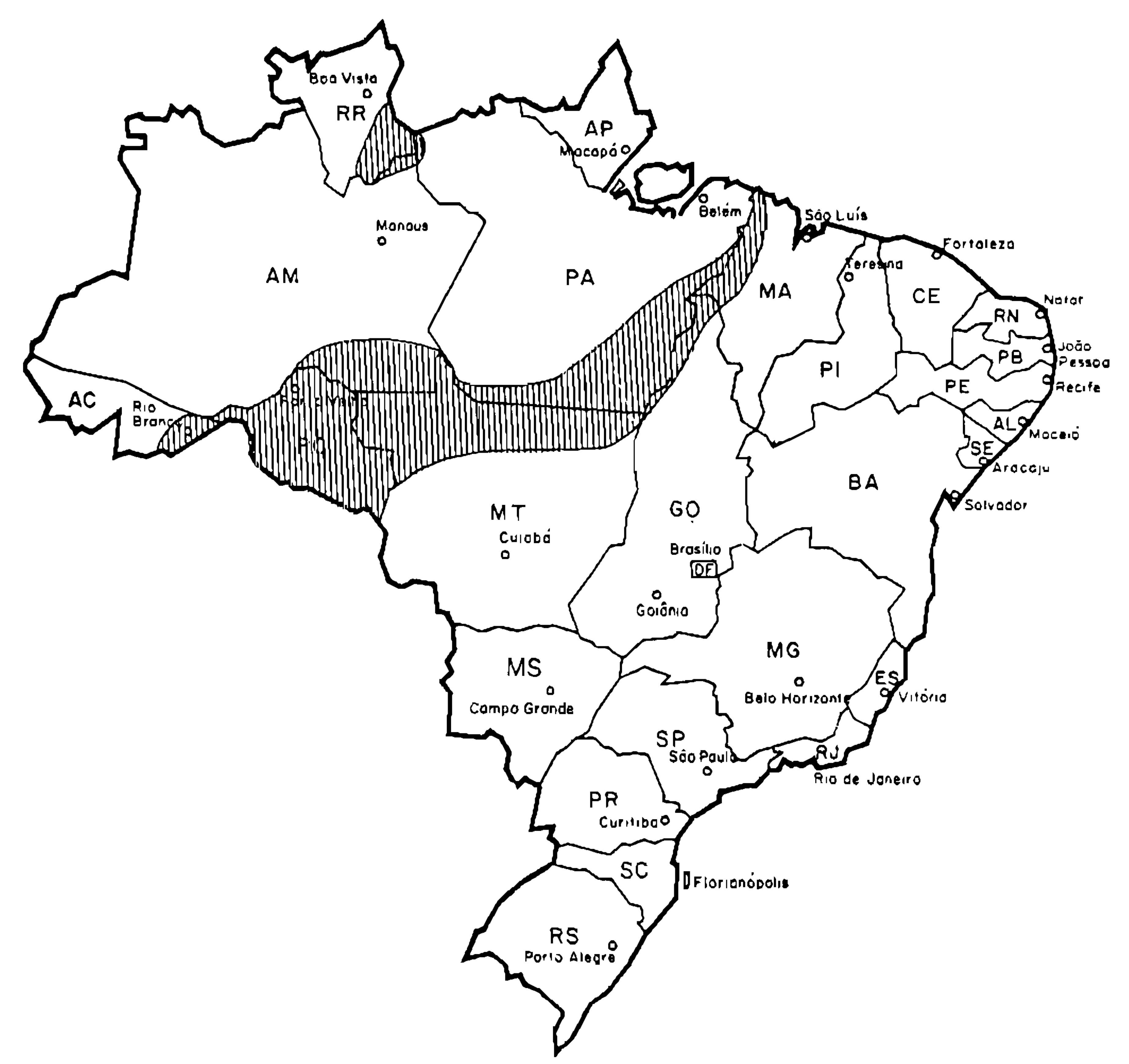

Map 5 - Prospecting/mining areas in the Legal Amazon region (schematic display) 


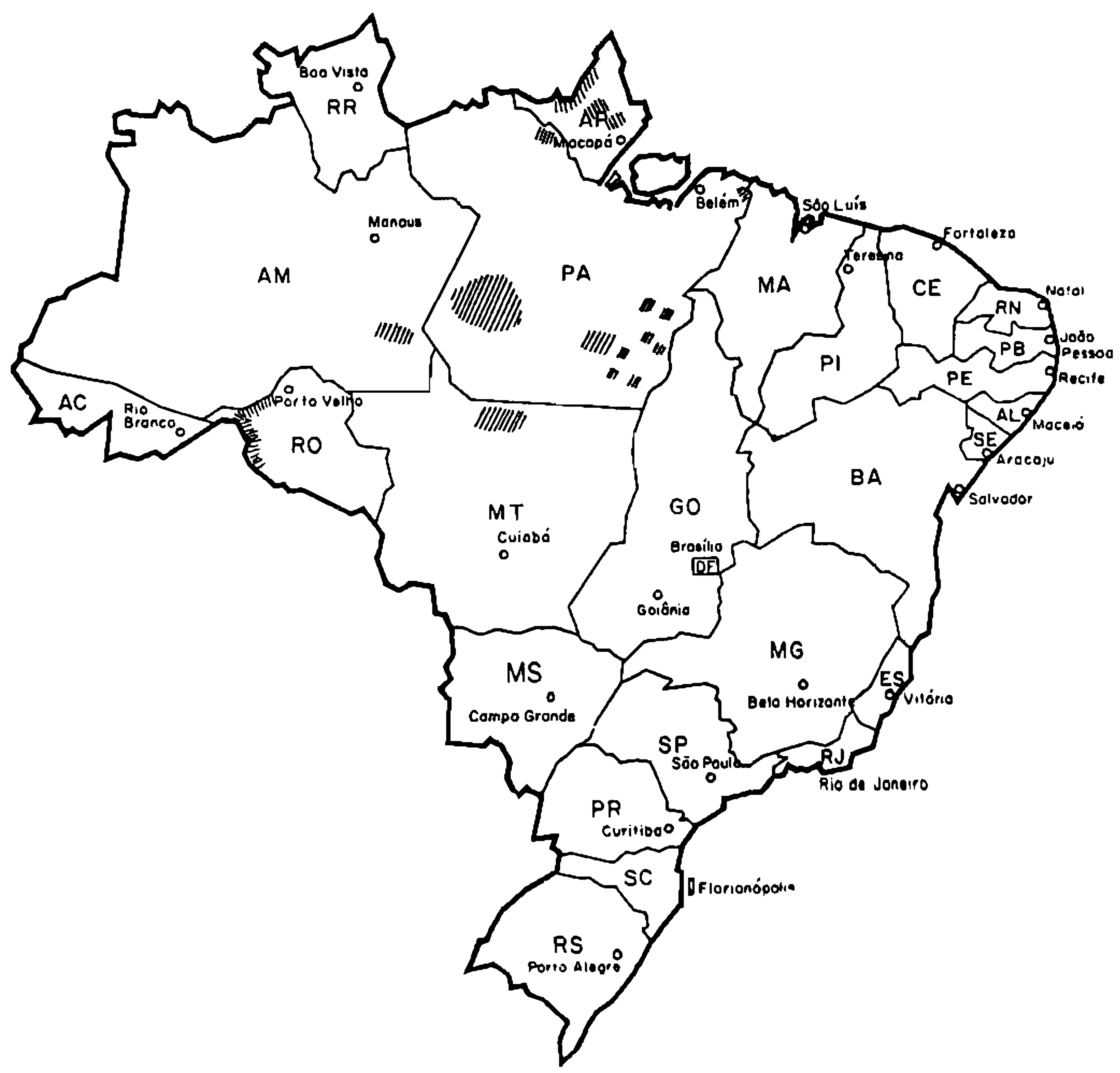

Map 6 - Settlement areas in the Legal Amazon region most affected by malaria in 1985 (schematic display)

The influence of these activities has been a decisive factor in the evolution of malaria in the Amazon region. In the case of the miners, the Cumaru complex produced deep changes in the epidemiological importance of the São Félix do Xingu Municipality and of the State of Pará itself (Table V).

The data above show clearly the larger share of São Félix do Xingu in the total number of malaria cases in the State of Pará, which coincides with the increase in the prospecting/mining operations in the municipality.

In Mato Grosso, out of the 12,832 cases of malaria registered in $1985,6,319$ came from mining operations or from areas under the influence of such operations, most of them from the municipalities of Colider, Alta Floresta and Aripuanã.

One of the best examples of what occur in the settlement zones is probably the Municipality of Ariquemes in the State of Rondonia, which has four INCRA settlement projects (Burareiro, Marechal Dutra, Machadinho, and Cujubim) and the largest number of malaria cases of any municipality in the country (Table VI).

Malaria does not seem to have much influence on the productivity of the mining operations. Despite the fact that the miners often suffer from the disease, they are either better able to seek health care or helped by the owner of the mining operation. After a malaria bout, they can immediately start mining again. In the case of the settler, malaria can have an impact of the whole agricultural production for a year if it hits at certain times, such as when clearing the land, during the burning of the brush or at harvest time. The situation of the settlers is worse because of the large debts and considerable expenditures involved when the whole family becomes ill (Sawyer \& Ferreira, 1986). 
TABLE V

Influence of the São Félix do Xingu Municipality on the epidemiology of malaria in the State of Pará 1981/ 1985

\begin{tabular}{|c|c|c|c|c|c|c|}
\hline \multirow[b]{2}{*}{ Year } & \multirow[b]{2}{*}{$\begin{array}{l}\text { Total No. } \\
\text { of cases } \\
\text { in Pará }\end{array}$} & \multicolumn{2}{|c|}{ Cases in São Félix do Xingu } & \multirow[b]{2}{*}{ Total } & \multirow[b]{2}{*}{ IPA } & \multirow[b]{2}{*}{$\begin{array}{l}\text { Share o } \\
\text { the Par } \\
\text { cases ( } \%\end{array}$} \\
\hline & & $\begin{array}{c}\text { Cases recorded } \\
\text { in the } \\
\text { municipality }\end{array}$ & $\begin{array}{c}\text { Cases recorded } \\
\text { in other } \\
\text { municipalities }\end{array}$ & & & \\
\hline $\begin{array}{l}1981 \\
1982 \\
1983 \\
1984 \\
1985\end{array}$ & $\begin{array}{r}51,792 \\
70,758 \\
116,685 \\
128,653 \\
112,812\end{array}$ & $\begin{array}{r}840 \\
731 \\
4,688 \\
14,204 \\
30,857\end{array}$ & $\begin{array}{c}\ldots \\
\ldots \\
4,286 \\
5,479\end{array}$ & $\begin{array}{r}840 \\
731 \\
4,688 \\
18,490 \\
36,336\end{array}$ & $\begin{array}{l}202.4 \\
105.8 \\
102.0 \\
411.4 \\
837.9\end{array}$ & $\begin{array}{r}1.62 \\
1.03 \\
4.02 \\
14.40 \\
32.20\end{array}$ \\
\hline
\end{tabular}

Source: Regional Directorate of the State of Pará

TABLE VI

Epidemiological data from the Ariquemes Municipality $1983 / 85$

\begin{tabular}{lrrr}
\hline & \multicolumn{2}{c}{ Blood Samples } & \\
\cline { 3 - 4 } & Examined & Positives & I L P \\
\hline 1983 & 59,276 & 20,194 & 34.1 \\
1984 & 90,433 & 30,932 & 34.2 \\
1985 & 115,532 & 38,287 & 33.1 \\
\hline
\end{tabular}

Note: The greatest influence within Ariquemes pertains to the Machadinho Project, in the family settlement phase, which had close to 12,000 cases of malaria in 1985.

These observations on the impact of malaria on two different types of migrants to the Amazon region: prospecting/mining and settlements. In both cases, man is exposed to the aggresthat it does not affect mining in the same fashion. This is due to the fact that family operations are particularly vulnerable, while in mining operations when individual workers become ill they are easily replaced.

Consideration must also be given to the activities of the malaria control agency, SUCAM, in its effort to decrease the magnitude of the problem to levels compatible with the development of the region.

The malaria control strategy has been almost exclusively based on the use of insecticides inside the dwellings and in the search for and treatment of cases, in order to halt the evolution of the disease and limit the sources of infection for the vectors. The results achieved fall considerably short of expectations. The vast distribution of anopheles, the occurrence of transmission throughout the year and the environmental factors make the Amazon region (particularly certain areas within it) a region of "hyperendemic" malaria in which the only means of attacking the problem has very little possibility of being successful because of the present conditions of land settlement. It is essential that other malaria control measures be incorporated to the present malaria control activities and that other institutions also become engaged in this undertaking.

The need for SUCAM to work more closely with other institutions that operate in the State of Rondonia is recognized. Such institutions are:

- the State Secretariat of Health, which has an important role to play in the standardization of diagnosis and treatment of the cases in its health care units, under the coordination of the Malaria Reference Center. This contribution will allow SUCAM to displace the microscopy technicians who are now located at the municipal headquarters to work in field laboratories at the site of rural outbreaks (mining operations would be included in this situation). 
- the SESP Foundation, that already provides good treatment to malaria patients and with which the purpose of working in closer association would be to standardize diagnosis and therapeutic management, with SUCAM providing the necessary input.

- city government authorities, which can contribute with the cleaning of mosquito breeding places and carrying out small environmental engineering works, for the purpose of reducing vector density and even attaining the halting of transmission in urban zones.

- the National Agrarian Reform and Settlement Institute - INCRA, with which SUCAM is already working closely, to reduce the impact of malaria in settlement projects through the search for better ways of preventing settlers from becoming malaric.

- research institutions that develop malaria projects, such as the Tropical Disease Insti. tute in Manaus, the National Institute for Research on the Amazon, the "Evandro Chagas" Institute, the "Oswaldo Cruz" Foundation, and the Center for Regional Development and Planning (CEDEPLAR).

- the National Department of Mineral Resources (DNRM) and the Miners' Union, to try to find proceedures which will help in the prevention and treatment of malaria and a decrease in the dissemination of the disease from the mining operations.

- the National Department of Works and Sanitation (DNOS), for eliminating anopheles breeding places in urban and periurban zones.

Anti-larvae work was much used in the past and may still be useful now whenever a decrease or the elimination of anopheles breeding places is intended. One way is to mechanically remove aquatic vegetation, along the banks, since this vegetation favors the laying of anopheles eggs in streams and even artificial catchments. It is recommended that the banks be kept clean and clear and that the floating vegetation be removed whenever feasible. Another important measure is the filling in of holes on the ground, particularly small and shallow ones. This is prescribed for waterlogged land and for places were water is collected at a level lower than that of neighboring streams, thus preventing vertical drainage. A third measure of this type would be drainage, for the purpose of facilitating the runoff of rainwater, of surface water which spreads and waterloggs the ground, and of surface outcrops of the groundwater table. This would eliminate anopheles breeding areas. The drainage can be carried out by means of cannals or ditches that correct the surface of the land or straighten small streams, preventing backwaters or stagnant waters.

Despite the measures that have been mentioned, it is certain that the Brazilian Amazon Region will be one of the last malaric areas in the Hemisphere. The Amazon region has been undergoing an dynamic process of settlement and exploitation that will continue for a long time, thus contributing to the presence of malaria during all that phase. This does not mean, however, that malaria must go on being a health problem. The stability of human settlements and the improvement of the settlers' living conditions would in themselves favor a decrease in the incidence of the disease, independently of any specific measures. Nevertheless, the success of the malaria control program will depend on the efficiency of control activities.

With regard to the control of migrants, an adequate analysis of the causes which underlie migrations in Brazil would show the practical futility of trying to control migrations flows directly. Neither can a great wall be built nor can there be a truly effective "filter" to migrations that would not also cause enormous losses. Nevertheless, when thinking of the alternatives to the control of migrants, the possibility of providing them with heal th care as well as adequate guidance about the best places to settle, from the stand point of health conditions, should not be discarted. A better structuring of the health care services and the enhancement of epidemiological surveillance will probably help meet this need.

\section{REFERENCES}

CENTRO DE DOCUMENT AÇĀO DO MINISTÉRIO DA SAÜDE (CDMS), 1982. Final Document. In: Seminário sobre transmissāo e controle de doenças tropicais no processo de migração humana. Proceedings, (Brasília) :183-201.

MARQUES, A.C., 1982. Migrações internas e dispersão de endemias. A Saúde no Brasil, (Brasília), I (4) :243251.

MARQUES, A.C. \& PINHEIRO, E.A., 1982. Fluxos de casos de malária no Brasil em 1980. Rev. Bras. Malariol. D. Trop., $34: 1-31$.

PALlA, J.A., 1986. Passado e presente de uma doença antiga. Mimeo. CEDFPLAR, UFMG, Belo Horizonte, MG, Brasil.

SAWYER, D.R. \& FERREIRA, A.H.B., 1986. Fstrutura produtiva, migração e malária: notas sobre duas áreas amazônicas. Mimeo. CFDEPLAR, UFMG, Belo Horizonte, MG, Brasil. 